\title{
Policy choice framework: guiding policy makers in changing farmer behavior
}

\author{
Geoff Kaine $^{1}, \underline{\text { Justine Young }}^{2}, \underline{\text { Ruth Lourev }}^{2}$ and Suzie Greenhalgh ${ }^{3}$
}

\begin{abstract}
There is a substantial literature on the characteristics of policy instruments. Unfortunately, there is an unhelpful degree of overlap in the strengths and weaknesses of different instruments. As a consequence, rarely is it the case that one particular instrument is obviously superior to all others. Policy makers must then make choices about which instrument(s) to use. The economics discipline can provide some insights for instrument choice through its exploration of market failures related to natural resource management. Few attempts, however, have been made to encapsulate these economic concepts in way to that could aid policy makers in these choices and ensure that policy instrument choice aligns with the fundamental cause of the behavior to be changed. We describe and provide example applications of the policy choice framework (PCF). The PCF was developed to assist policy makers to deliberately and systematically choose policy instruments to influence the behavior of farmers. The PCF is unique among methods for choosing policy instruments because it links the microeconomic reasons underpinning the choice of a primary policy instrument (stage one) with predictions of the behavior of farmers (stage two) and predictions about the organizational needs of agencies responsible for implementing policy (stage three). We describe the PCF using two applications: wild dog management and the control of agricultural nitrogen discharges. Our purpose was to show how the PCF could be employed to assist in policy instrument selection. We then discuss the implications for policy design and instrument choice.
\end{abstract}

Key Words: adoption; compliance; natural resource management; policy implementation; policy instrument choice; water quality; wild dogs

\section{INTRODUCTION}

The intent of much agricultural and natural resource policy is to change the behavior of farmers to achieve a specified outcome. There are a variety of policy instruments that may be employed to do this. Some instruments, such as regulations, are intended to compel changes in behavior. Others, like incentives, are intended to induce voluntary changes in behavior.

There is a substantial literature on the characteristics of policy instruments, their strengths and weaknesses, and an extensive set of criteria for choosing between them (OTA 1995, Gunningham et al. 1998, Vedung 1998, Russell and Powell 1999, Australian Public Service Commission 2009, United Nations Environment Programme 2009, Greenhalgh and Selman 2014, Mees et al. 2014). However, there is an unhelpful degree of overlap in the strengths and weaknesses of different instruments (Goulder and Parry 2008). As a consequence, rarely is it the case that one particular instrument is obviously superior to all others. Policy makers must then make choices about which instrument(s) to use, despite efforts to better define the circumstances governing instrument success (Taylor et al. 2012, Craig and Roberts 2015).

The economics discipline can provide some useful insights for instrument choice through its exploration of market failures related to natural resource management. ${ }^{[1]}$ Few attempts, however, have been made to encapsulate these economic concepts in a way that could systematically and deliberately aid policy makers in these choices and ensure policy instrument choice aligns with the fundamental cause of the behavior to be changed (Randall 1983). There are some exceptions, e.g., Pannell (2008), Connor et al. (2009), and Mees et al. (2014). However, these exceptions do not provide policy makers with a means of (i) identifying the fundamental cause, from a microeconomic perspective, of the natural resource problem they face; and (ii) inferring from the fundamental cause the policy instrument that would be feasible and efficient in resolving the resource problem.

For example, Pannell (2008) draws on microeconomic theory but does not use market failure criteria to choose between policy instruments. Connor et al. (2009) use decision trees to arrive at a preferred policy instrument using elimination-by-aspects but do not explicitly use microeconomic criteria. Mees et al. (2014) propose a step-wise process for choosing a policy instrument and suggest efficiency as a criterion without describing the microeconomic foundations of efficiency (market failure) and how these foundations relate to natural resource management problems.

Our aim is to describe a framework, the policy choice framework (PCF), which has been designed to fill this gap. The PCF is a tool to assist policy makers to apply the principles of market failure to identify the fundamental causes of the policy problem they face and, through an elimination-by-aspects process (Tversky 1972), identify a feasible and efficient policy instrument to influence farmer behavior.

In contrast with the multicriteria decision-making approaches that others have employed (Bryan and Kandulu 2011, Velasquez and Hester 2013) the decision trees in the PCF allow policy makers to choose between the major types of instruments following an elimination-by-aspects process that is in keeping with the theory underpinning the concept of market failure. By directly linking instrument choice with fundamental differences in the nature of the market failure, the PCF advances the theory of policy instrument selection. In principle, policy makers operating within a traditional, or a participative (Ostrom 2009, Cox et al. 2010, Holley et al. 2013), model of resource governance can employ the PCF. 
The PCF also differs from most other tools for choosing policy instruments because, having identified a primary policy instrument based on market failure criteria, the resulting choice is then linked through a series of decision trees with predictions of farmer response to the policy, and predictions about the organizational needs of agencies responsible for implementing policy (see Appendix 1).

This paper is based on the application of the PCF to irrigation modernization in Australia (Johnson, Kaine, Sandall, and Murdoch 2009, unpublished manuscript), wild dog management in Australia (Lourey et al. 2011), and to nutrient management in Australia and New Zealand (Kaine et al. 2008, Young and Kaine 2010). We describe the literature the PCF draws from and how this literature is used to choose between different policy instruments. We outline the application of the PCF to wild dog management and nutrient management before discussing the implications of these applications for policy design.

\section{THEORY}

\section{Overview of the policy choice framework}

The PCF's goal is to determine how to change farmer behavior. This means a policy objective or outcome must be formulated and the behaviors that contribute to, or detract from, the policy outcome need to be identified. The policy decision is, therefore, how to encourage any desirable behavior because it contributes to the policy outcome, and how to discourage any undesirable behavior because it detracts from the outcome.

The PCF contains three distinct but related stages (see Fig. 1), with a series of decision trees to guide a policy maker through each stage. In the first stage classical microeconomic theory in relation to market failure (Randall 1983) is employed, along with other criteria, to systematically exclude policy instruments from consideration because they are not efficient, or politically or technically practical. Ideally, the principal or primary instrument for changing farmer behavior emerges. Some policy problems, however, encompass more than one kind of market failure (Goulder and Parry 2008) and repeated applications of the PCF are required in such circumstances.

Having identified an instrument, the next stage assesses how farmers react to the instrument, and if they will change their behavior as expected. A combination of farm systems theory and social psychology are used to predict farmers' reactions to the policy instrument and forecast changes in their behavior. This stage determines the feasibility of the primary instrument in terms of farmers' reactions (perhaps with some modification or use of complementary policy measures).

Key to the successful implementation of policy is the structure and resourcing of implementing agencies. As instruments differ, different organizational procedures, processes, structures, and even cultures are required for their successful implementation. In the third stage a combination of organizational behavior theory and systems theory is used to predict the organizational changes that may be required for agencies to successfully implement the primary policy instrument and any complementary measures. This stage confirms if the primary instrument (and any complementary measures) is feasible to implement from the implementing agencies perspective.
Fig. 1. Overview of the policy choice framework.

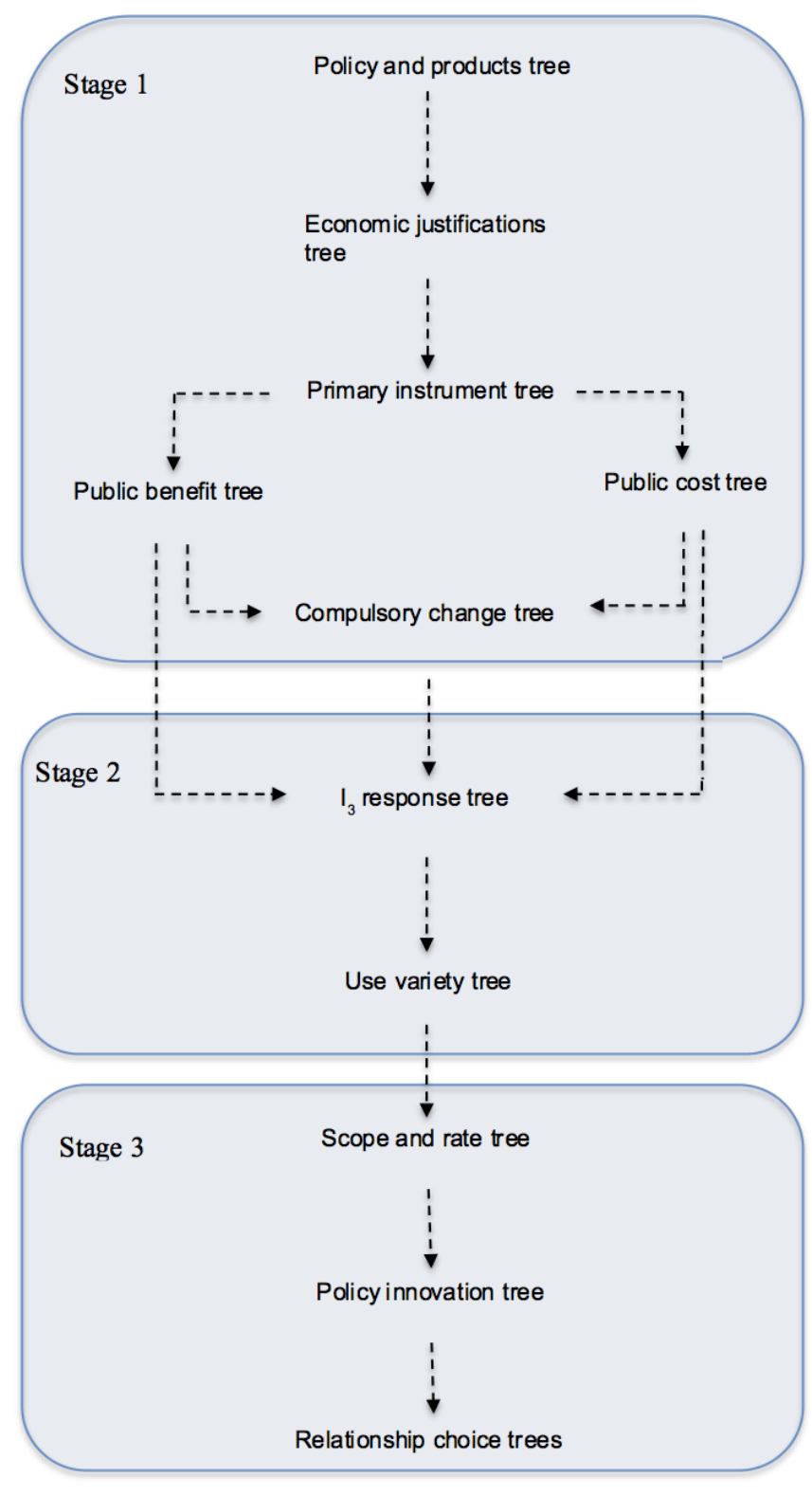

Stage one: choosing a policy instrument

Microeconomic theory on market failure (Henderson and Quandt 1980, Randall 1983) guides the selection of a policy instrument. In theory, the unrestricted operation of purely competitive markets should maximize social welfare. In practice markets may not be purely competitive and, as a consequence, government intervention in the economy may be justified to improve social welfare. When markets persistently, substantially, and systematically fail to allocate resources to their most highly valued use then they are inefficient. The crucial term here is "persistently" because this signals the presence of a fundamental flaw in the operation of markets (Randall 1983). Inefficiency occurs when markets are missing, incomplete, or imperfect. ${ }^{[2]}$ These represent 
different forms of market failure and each provides a necessary, though not sufficient, justification for government intervention. For government intervention to be fully justified it is also necessary to establish that the social benefits of the chosen intervention outweigh the costs (Stern 2007).

Randall (1983) identified two properties for identifying why markets are missing or incomplete and so are persistently inefficient: nonexclusiveness and nonrivalry. Nonexclusiveness occurs when either the supplier of a product/service is unable to obtain payment in full from those that benefit from the product/ service; or the user of a product/service can avoid paying the full cost of using the product/service. Nonrivalry occurs when the use of a product/service by one individual does not affect the use of a product/service by others.

When both conditions are present the market is missing. When a market exists for a product/service but the supply or use of the product/service creates costs or benefits that are not fully reflected in its price (Vatn and Bromley 1997) then the market is incomplete (Randall 1983). In other words, there are nonexclusive benefits or costs associated with the supply or use of the product/service. Persistent failure to adequately price all costs and benefits associated with the supply or use of a product/service implies rivalry, but nonexclusivity, in at least one of the inputs or resources involved in the supply or use the product/service. Such nonexclusive benefits or costs are commonly termed positive or negative externalities, respectively (Randall 1983) and are the feature of missing markets. Imperfect markets such as monopolies arise when an agent in the market can influence the market price.

When markets are incomplete and create nonexclusive benefits (costs) then the supply or use of the relevant input or resource will be less (more) than is economically optimal. This means the welfare of the community can be improved by encouraging (discouraging) supply or use of the relevant product/service.

To apply microeconomic theory the behavior of interest is translated into the supply, or use, of a product/service. The PCF "policy and products tree" uses the following criteria to translate behaviors (or actions) into products/services:

- Is the action consistent with the policy objective?

- Will the action be taken voluntarily in the absence of a policy intervention?

- Will a business or an individual take the action (Kaine and Lourey 2012)?

The "justifications tree" uses market failure to characterize the fundamental reason why farmers are not supplying or using a product/service (when this is desirable), or why they continue to supply or use a product/service (when this is undesirable). This fundamental reason for the behavior of interest provides the technical justification, from an economic perspective, for government to intervene to change the farmer behavior. The decision to actually intervene will depend on whether the overall benefits of intervening outweigh the overall costs.

Next a policy instrument to counteract the fundamental cause of the persistent behavior is identified. This is done in the PCF using four trees, the "primary instrument," "public benefits," "public costs," and "compulsory change" trees.
The choice of policy instruments depends on the following:

- Whether there are economies of scale in supply of a product or service (Henderson and Quandt 1980);

- Whether the rights of those that experience uncompensated costs or benefits have priority over the rights of those who create uncompensated costs or benefits;

- Whether the supply or use of the relevant product or service can be measured;

- Whether the value of the public benefits or public costs associated with the supply or use of the relevant product or service can be measured (Kaine and Lourey 2012).

Policy instruments tend to be either incentives to promote voluntary changes in behavior or regulations, taxes and charges, and quantity-based market instruments to compel changes in behavior. While recognizing there are many forms of standards, regulation can be usefully classified into three kinds: performance standards, technology standards, and process standards (Gunningham et al. 1998, Bluff and Gunningham 2004).

Where the individual supply (or use) of the product or service that creates a public benefit (public cost) is relatively easy and inexpensive to measure then market instruments such as a tax or cap-and-trade scheme, or performance standards can be employed (Gunningham et al. 1998). The choice between these depends on whether individual differences in the value of creating the benefit (or cost) can be measured relatively inexpensively. If this is the case then market instruments are feasible. If not then performance standards are the better option.

Where individual differences cannot be measured technology or process standards are best used. If the public benefits (or costs) are strongly influenced by the type of technology/materials used in the behavior then technology standards are more appropriate (Bluff and Gunningham 2004). Where the creation of public benefits (or costs) depend on how technology/materials are used then both technology and process standards may be necessary (Bluff and Gunningham 2004). In principle, this stage of the PCF could also be used in other domains such as health, education, transport, and crime.

\section{Stage two: predicting farmers' responses}

How farmers react to the primary instrument is assessed next using the "I $\mathrm{I}_{3}$ response" and "use variety" trees. Although approaches such as those described by Black (2000) and Knowler and Bradshaw (2007) could be used, the PCF uses a combination of farm systems (Crouch 1981), social psychology (Derbaix and Vanden Abeele 1985) and marketing (Shih and Venkatesh 2004) theory to ascertain farmers' reactions and their expected behavior changes (Kaine and Higson 2006a, Kaine et al. 2010).

If farmers react favorably there are likely few implementation barriers. However, if they react unfavorably they may behave in counterproductive ways, and changing how the primary instrument is implemented should be explored to counteract this response, e.g., using a complementary measure such as offering incentives (Kaine et al. 2010). When farmers' reactions are so unfavorable it is not politically feasible to implement the instrument then the choice of primary instrument should be revisited. 
In some instances, even though farmers are expected to react favorably, insufficient farmers change behavior to meet the policy outcome. Or, the pace of change may be too slow to achieve the policy deadline. Again, additional policy measures may be required, or the choice of the primary instrument reconsidered. For example, a regulated code of conduct may replace a voluntary industry code of conduct as the primary instrument to ensure all businesses in an industry meet certain operating standards.

The "scope and rate" tree is used to predict the number of farmers and the rate of behavior change. This is based on a combination of farm systems (Crouch 1981), innovation (Abernathy and Clark 1985, Henderson and Clark 1990), and consumer purchase (Kapferer and Laurent 1986, Assael 1998) theory to assess the rate of behavior change.

\section{Stage three: predicting agency responses}

Because the principles underpinning the design and operation of policy instruments differ, different organizational procedures, processes, structures, and even cultures are required to successfully implement different policy instruments (Abernathy and Clark 1985, Rist 1998, Kaine and Higson 2006b, Kaine et al. 2006). Therefore, a new instrument may require agencies to adapt to meet new needs, all of which require resourcing. The "policy innovation" tree uses a combination of organizational behavior and systems theory (Abernathy and Clark 1985) to predict what organizational changes may be required to successfully implement the primary policy instrument.

Often, the authority, responsibility, and resources for the design and implementation of agricultural and natural resource policy are distributed among different organizations (Rist 1998, Petris 2004, Considine 2005). This creates similar circumstances to those that arise with outsourcing in business. Outsourcing involves contracting with a supplier from outside an organization for the provision of goods and services that, traditionally, would have been provided internally within the organization (Hunter 2004). This creates dependencies between organizations because achieving one organization's objectives depends upon another organization achieving their objectives (Hunter 2004) resulting in governance and strategic risks.

The "relationship choice trees" are intended to help predict the governance and strategic risks that may arise when policy design and implementation activities are shared among a set of organizations. This uses a combination of economic (Williamson 1979, 1991), strategy (Porter 1985, 1996), and human resource (Rousseau 1990, Legge 2005) theory to identify the potential risks of distributing the responsibility for developing and implementing natural resource policy among a group of organizations (Kaine and Keeble 2007, Keeble et al. 2008).

\section{APPLICATION}

Wild dog control in Australia and agricultural nutrient discharge management in New Zealand are policy challenges we use to demonstrate the application of the PCF.

\section{Wild dogs}

Wild dogs are a well-established pest species in Victoria, Australia. They attack livestock, adversely affect dingo (native dog) populations, present human and livestock disease problems, and may, potentially, threaten human safety (King 2008). Although livestock losses are usually confined to properties adjoining public land where wild dog populations are concentrated, attacks can occur elsewhere (King 2008).

Public and private landowners have legislated responsibility to take all reasonable steps to prevent the spread of, and as far as possible eradicate, established pest animals such as wild dogs (Department of Primary Industries 2010). Control activities include trapping, poisoning, and shooting while exclusion fencing and guard animals reduce wild dog attacks.

Stage one: policy instrument for wild dog control

In the absence of policy few farmers would voluntarily undertake control activities. Thus the policy objective is for farmers to prevent or reduce wild dog attacks. These actions are the supply of a pest control service by farm businesses to reduce the frequency of wild dog attacks.

Without government intervention, control measures such as baiting, shooting, and trapping are nonexclusive in production because an individual farmer who takes these measures cannot exclude other farmers from also benefitting. Nor can they compel other farmers to pay for the protection they receive. These control measures are also nonrival in consumption because the protection one farmer receives from the service, i.e., reduced wild dog attacks, does not exclude other farmers from receiving similar benefits. This means there is a missing market for the private supply of pest control services for wild dogs justifying government intervention to create the supply of the service.

The purpose of the primary instrument is, therefore, to supply a pest control service for wild dogs. Because economies of scale are unlikely to exist, incentives to encourage farmers to voluntarily supply the service, or instruments that compel farmers to supply the service are the possible instruments. The preferred option depends on whose rights have priority: the rights of farmers who would have to change their behavior, or the rights of those in the community who benefit from the change. Many farmers and, in principle, the wider community experience uncompensated benefits from reduced numbers of wild dogs, including fewer livestock and wildlife losses, less hybridization of dingoes, less environmental degradation, and fewer potentially negative health impacts.

Given landowners legally have to take reasonable steps to control wild dogs, it seems reasonable that the rights of those who gain uncompensated benefits have priority over the rights of individuals that create the benefits. Hence, a policy instrument that enforces compulsory supply is more appropriate.

With shooting, public benefits are created as wild dogs are killed. Because individuals know the costs they incur a market instrument may be feasible. Therefore, a type of cap and trade scheme could be introduced, e.g., a landholder-funded bounty system with limited transferable permits to kill wild dogs. A cap on the number of transferable permits is necessary to establish exclusiveness in supply of the service and, therefore, value in possessing a permit.

Measuring the public benefit created by activities, such as fencing and baiting, is more challenging because market mechanisms or performance standards are unlikely to be feasible. Instead, the options are (1) regulating technology/materials, or (2) regulating 
the management of technologies/materials, e.g., timing and placement of baits.

Stage two: farmers' responses to wild dog control policy options The enforcement of technology and process standards for wild dog control by farmers is prohibitively expensive, if not impractical. Consequently, compliance by farmers with standards becomes, largely, voluntary. Hence the supply of these services becomes a matter of coproduction (Wright et al. 2011a,b). Community-led control activities, supported by incentives, are probably the only practical approach to maximizing control activities and compliance with control standards, e.g., payment of incentives subject to meeting exclusion fencing standards. ${ }^{[3]}$ Because farmers were highly involved with the policy objective of reducing wild dog attacks they had formed a definitive view about what control methods (including the public provision) would work best for them, and were motivated to participate in developing and implementing community-led, coordinated programs. The Victorian government, to a limited degree, has adopted this community-led approach.

Stage three: agency responses to wild dog control policy options The Victorian government had, for some time, taken a consultative approach to wild dog control programs. The PCF, however, suggests there should be greater program flexibility and community participation in program planning and decision making.

The variation in preferred control measures among farmers means the success of community-led programs depend on program flexibility to accommodate these differences. This meant having sufficient capacity to co-ordinate different control activities as well as offer incentives for control activities (Lourey et al. 2011). This led to a modular change in program design and implied a collaborative rather than consultative approach to community engagement for planning and resource allocation (Lourey et al. 2011). Because farmers had devoted considerable time and effort to developing their views on control activities, they believed they had expertise in this area. Consequently, if consulted on program design, they expected to be included in decisions about program strategy and operations, and to influence the allocation of program funds and other resources (Lourey et al. 2011). However, this radical change in how to design control programs was not acceptable to the implementing agency and control over planning and resourcing has remained with the agency.

\section{Nitrogen discharges}

Lake Taupo is New Zealand's largest lake. Approximately $20 \%$ of the catchment is pastoral farming, mostly mixed sheep and beef enterprises, $25 \%$ is commercial forestry, and the remainder is native forest with a small proportion in urban use.

Despite excellent lake water quality with low nitrogen and phosphorus concentrations and little algal growth there were signs of gradual water quality deterioration. There were also increases in nitrogen in several streams flowing into the lake from agricultural areas. Modeling studies indicated water quality could be adversely affected if nitrogen leaching from agricultural land was not addressed (Elliot and Stroud 2001). This led the regional council $^{[4]}$ to take steps to halt any further water quality deterioration.
Stage one: policy instrument to reduce nitrogen discharges The policy intent was for farmers to reduce nitrogen discharged to the lake. Without policy intervention most, if not all, farmers will continue to leach nitrogen using the capacity of the lake to absorb nitrogen. Therefore, the market failure relates to the capacity of Lake Taupo to assimilate nitrogen. The limited assimilative capacity of the lake means it is rival in use. Nitrogen discharges by farmers create costs for third parties such as tourists, fishers, and Māori, i.e., New Zealand's indigenous peoples, and farmers do not compensate these third parties for these costs. This creates nonexclusive costs or negative externalities, indicating an incomplete market for nitrogen. The purpose of the primary instrument, therefore, is to limit the use of the lake to assimilate nitrogen discharge.

As the wider community faced uncompensated costs with water quality declines, the council determined that these costs were unacceptable to the community (Young and Kaine 2010). Consequently a policy instrument that forced farmers to reduce nitrogen discharges was determined as appropriate, e.g., regulation, taxes, or charges, or some form of market instrument, rather than voluntary approaches.

In contrast to the wild dog application, individual use of the resource, and therefore contribution to public cost, could be estimated relatively easily and inexpensively using models that predict agricultural nitrogen discharges. The heterogeneity of farms in terms of size, topography, soils, elevation, rainfall, livestock type, and stocking intensity creates differences in the cost to reduce discharges, making market instruments feasible. Ultimately, following extensive farmer engagement, the council settled on a cap-and-trade scheme as the most suitable market instrument for controlling farmers' use of the lake's assimilative capacity.

Stage two: farmers' responses to nitrogen discharge policy options Farmer engagement in community consultation and planning processes indicates at least moderate farmer involvement with the policy problem of maintaining lake water quality. Their extensive participation in political activity and planning processes also signaled high involvement in the proposal to implement a capand-trade market (Young and Kaine 2010).

Farmer attitudes toward a cap-and-trade market were largely unfavorable, but less unfavorable than their attitudes to technology or process standards (Young and Kaine 2010). Farmers preferred a cap-and-trade market because when farm discharges were restricted the market gave farmers flexibility in how they reduced their discharges and allowed the transfer of discharge permits between farmers.

Farmers' attitudes toward the cap-and-trade market were favorably influenced by the council decision to allocate discharge permits based on historical discharges, i.e., there was no regulated reduction in their existing nitrogen discharges. This reduced any immediate financial and social disruption farmers faced (Young and Kaine 2010). Therefore, the potential for unfavorable farmer reactions and implementation risk was considered low. Ultimately a cap-and-trade market was established alongside a trust with the finances to achieve the necessary reduction in nitrogen by purchasing land and discharge permits (Waikato Regional Council 2014, Kerr et al. 2015). 
Stage three: agency responses to nitrogen policy options The council's policy experience was mostly in regulatory policies based on performance, technology, and process standards. Capand-trade markets are different to standards and were new to the council. This was a radical policy innovation for the council requiring organizational changes that the council undertook.

New processes and procedures were developed and specialist knowledge, skills, and experience in market systems were acquired by redeploying staff from external agencies. At the same time there were changes in the roles, responsibilities, and relationships between functional groups in council. As expected, these wide ranging changes were disruptive and required considerable time and resources to successfully implement (Young and Kaine 2010).

Nutrient benchmarking of farmers and the acquisition of nutrient permits by the trust were two important implementation activities and they posed some outsourcing risks. Outsourcing benchmarking activity appeared low risk because benchmarking was becoming a standardized service. Outsourcing permit acquisition was higher risk because the acquisition process and the rate the trust could achieve its objectives could not be precisely defined in advance. This suggests that the relationship between the council and the activity was subject to bilateral, even unilateral, governance.

Ultimately, both activities were outsourced, to the Lake Taupo Protection Trust (http://www.laketaupoprotectiontrust.org.nz/ page/lake 5.php\#the-trust-role). Consequently, the creation of management structures and systems to ensure coordination of activities between the council and the trust was critical to the success of the policy.

\section{DISCUSSION}

Key policy design decisions

Applying the PCF to real world policy problems identified important policy design and implementation considerations. First, primary instrument choice depends on a few key decisions related to economies of scale, priorities in regard to individual and community rights, and the practicality of measuring actions and outcomes.

Determining if economies of scale are present is a technical consideration governed by underlying technologies. For example, economies of scale were unlikely to arise in the control of wild dogs, and unlike other services such as education, research, and defence, there was not any merit in the public provision of wild dog control services. ${ }^{[5]}$

Setting priorities around individual and community rights is a social decision. Whose rights have primacy determines whether the instrument should force compulsory change (regulation though technology or process standards or market instruments) or encourage voluntary change (incentives). For example, in Lake Taupo the council determined, based on community consultation, that the uncompensated costs imposed on the community by farmers discharging nitrogen were unacceptable. Therefore, the community's rights took precedence over farmer rights and an instrument compelling farmers to change was acceptable.

The practicality of measuring actions and outcomes is a technical consideration determined primarily by technology and scale.
Measurement is critical to instrument choice because the ability to measure or infer the creation of benefits or costs is required for market instruments or performance standards to be feasible. Where individual creation of a public benefit or cost cannot be easily measured then only technology or process standards is feasible.

With wild dogs, measuring outcomes was impractical for most control activities. Even measuring (observing) some control actions is prohibitively expensive. Consequently, although regulations exist governing the supply of control wild dog services by farmers, they are virtually unenforceable. In contrast, the acceptance of a scientific model that estimated nitrogen discharges based on farmer actions enabled the use of a market mechanism in Taupo.

\section{Instrument design and equity}

A second consideration was equity and policy instrument choice. The PCF is designed to help choose policy instruments that correct inefficiencies in the economy, not to correct inequalities in the economy, which is also a key concern of policy makers (Rose and Stevens 1993, Myles 1995, Howe 2000). However, actions to correct inefficiencies will alter the distribution of income and wealth, possibly in ways considered unfair (Myles 1995). Despite this, the choice of the primary instrument should not be influenced by potentially unacceptable inequalities. Instead any inequalities should be addressed using secondary instruments, such as transfer payments, specifically designed to correct inequalities rather than modify the primary policy (Tinbergen 1950, Eskeland and Jiminez 1991, Kaine et al. 2017).

Equity is considered, however, in two ways in the PCF. Equity may be considered when determining whose rights have priority, either the community experiencing uncompensated costs or benefits or the subset of the community creating the uncompensated costs or benefits. This decision will be influenced by the magnitude of these costs and benefits for affected parties. In reality, though, the aggregate costs and benefits of change can only really be assessed once the primary instrument has been chosen. At this point a complementary mechanism can be formulated to redistribute costs accordingly. In the Lake Taupo case, the costs of reducing nitrogen discharges were shared among farmers, ratepayers, and taxpayers, largely by establishing an independent trust to achieve the necessary reduction in nitrogen discharges.

Equity is also considered during instrument design, e.g., when deciding how to allocate discharge permits, developing eligibility rules for incentives or rules for who is regulated. These considerations influence the distribution of gains and losses among farmers, i.e., the fairness, or otherwise, of how farmers are treated relative to each other.

\section{Structuring policy design processes}

A third consideration is the speed, and therefore cost, policy instruments are chosen, crafted, and implemented. Although the PCF was applied after the wild dog and nutrient discharge policies had been chosen, its application yielded policy prescriptions broadly consistent with the chosen policy. This suggests the underpinning theories used to develop the PCF are broadly consistent with policy practice and can provide a formal logical way of structuring and justifying the policy design process. In the 
Lake Taupo case, if the council had used the PCF through the policy process they would have been able to transparently and systematically articulate the fundamental reasoning to politicians as to why a cap-and-trade market was the preferred instrument for limiting nitrogen discharges (Young and Kaine 2010).

The explicit, theoretically sound, and systematic incorporation of farmers' reactions in the policy design process also identifies unfavorable farmer reactions early in the policy process. Unfavorable stakeholder responses to policy are a key challenge in any policy process (Grimble and Wellard 1997, Smith and Sime 2007, Young and Kaine 2010, Godwin 2016). Formally assessing potential responses during the policy choice process creates opportunities to consider and develop appropriate strategies for engaging with farmers, modifying instruments, or even abandoning particular instruments. With both wild dog control and limiting nitrogen discharges the PCF highlighted variation in farmer reactions to proposed policy instruments. With wild dogs, there were differences among farmers in preferred control methods (Lourey et al. 2011) and in Lake Taupo there were varied responses to how to regulate nitrogen discharges across diverse farm contexts (Young and Kaine 2010). Therefore, the PCF provides an approach to reduce, to some degree, awkward surprises for policy designers and politicians (Rist 1998).

\section{CONCLUSION}

There is a substantial literature on the characteristics of policy instruments, their strengths and weaknesses, and criteria for choosing between them. However, few tools draw on microeconomic theory around market failure to assist policy makers to choose policy instruments. It is this gap the PCF is designed to address.

Using examples of wild dog management in Victoria, Australia and agricultural nitrogen discharge control in Lake Taupo, New Zealand, we showed how the PCF could identify an initial preferred policy instrument for changing the behavior of farmers. The development and application of the PCF has revealed that, to our surprise, only three factors have a critical influence when it comes to choosing between policy instruments using this approach: whether economies of scale are present, whether the change in farmers' behavior should be voluntary or compulsory, and whether it is practical to measure outcomes or actions of farmers. We also found the PCF could play a role in reducing the confounding effects of equity considerations in policy instrument choice. In addition, the PCF can potentially accelerate the policy design process, reduce costs, and avoid, to some degree, awkward surprises for policy designers and politicians.

Given policy design is increasingly challenging as natural resource issues and solutions become more complex and there is greater stakeholder awareness around the impacts of natural resource use, it is timely that frameworks such as the PCF are developed to aid the policy process. Its decision-tree structure is intended to help policy makers deliberately and systematically choose policy instruments to influence farmer behavior. The PCF is unique among methods for choosing policy instruments because it links primary policy instrument choice, based on the nature of market failure giving rise to the policy problem, with predictions of farmer behavior and predictions about the organizational needs of implementing agencies. In other words it considers not only the natural resource problem, in its wider context, but also how people, both affected parties and policy administrators, interact with the proposed policy instruments. By bringing the human dimension alongside the physical elements of resource management problems, policy makers are enabled to better understand the implications and reactions to policy instruments earlier and to provide an opportunity for more constructive debate and discussions around how best to address increasingly complex natural resource problems.

${ }^{[1]}$ We acknowledge that other equally important criteria such as legitimacy and equity also influence the choice of policy instrument.

${ }^{[2]}$ The terms "public goods" (missing markets) and "externalities" (incomplete markets) have been avoided because there is confusion about the meaning of "public goods" and "the public good" among noneconomists. Similarly to talk of market failure can confuse because it implies the presence, rather than the absence, of a market.

${ }^{[3]}$ In some Australian states, wild dog bounties are used as incentive payments but are not part of a structured market instrument.

${ }^{[4]}$ Regional councils are the regulatory authority in New Zealand responsible for managing freshwater resources.

${ }^{[5]}$ Note that, the PCF activities such as extension and promotion are not treated as policy instruments even though they are often described as such. These activities are not, strictly speaking, policy instruments. They are services. The policy instrument is the public provision of these services.

Responses to this article can be read online at: http://www.ecologyandsociety.org/issues/responses. php/9135

\section{Acknowledgments:}

The policy choice framework has been developed over a number of years and draws on the knowledge and effort of many people. The framework originated from research supported by the Victorian Water Trust, the Victorian Department of Sustainability and Environment, and the Goulburn Broken Catchment Management Authority. The National Action Plan for Salinity, the Victorian Climate Change Adaptation Program, and the Victorian Department of Primary Industries were contributors to development and revision of the Framework, and various components in it. The Waikato Regional Council, Landcare Research New Zealand, and the Ministry of Business Innovation and Employment's Science and Innovation Group, who funded the Freshwater Values, Monitoring and Outcomes Programme (C09X1003), were instrumental in promoting and supporting the development of the final organizational components of the PCF, the integration of all the components of the PCF into a primer, and the preparation of this paper. We would like to thank our anonymous referees for their insightful comments and suggestions.

\section{LITERATURE CITED}

Abernathy, W., and K. B. Clark. 1985. Innovation: mapping the winds of creative destruction. Research Policy 14:3-22. http://dx. doi.org/10.1016/0048-7333(85)90021-6 
Assael, H. 1998. Consumer behavior and marketing action. South Western College Publishing, Cincinnati, Ohio, USA.

Australian Public Service Commission. 2009. Smarter policy: choosing policy instruments and working with others to influence behaviour. Commonwealth of Australia, Australian Public Service Commission, Canberra, Australia.

Black, A. W. 2000. Extension theory and practice: a review. Australian Journal of Experimental Agriculture 40(4):493-502. http://dx.doi.org/10.1071/EA99083

Bluff, E., and N. Gunningham. 2004. Principle, process, performance or what? New approaches to OHS standards setting. Pages 12-42 in E. Bluff, N. Gunningham, and R. Johnstone, editors. OHS regulation for a changing world of work. Federation Press, Leichhardt, New South Wales, Australia.

Bryan, B. A., and J. M. Kandulu. 2011. Designing a policy mix and sequence for mitigating agricultural non-point source pollution in a water supply catchment. Water Resources Management 25:875-892. http://dx.doi.org/10.1007/s11269-010-9731-8

Connor, J., D. Hatton MacDonald, M. Morrison, and A. Cast. 2009. Evaluating policy options for managing diffuse source water quality in Lake Taupo. Environmentalist 29(4):348-359. http://dx. doi.org/10.1007/s10669-008-9197-x

Considine, M. 2005. Making public policy. Polity Press, Cambridge, UK.

Cox, M., G. Arnold, and S. Villamayor Tomás. 2010. A review of design principles for community-based natural resource management. Ecology and Society 15(4):38. http://dx.doi. org/10.5751/es-03704-150438

Craig, R. K., and A. M. Roberts. 2015. When will governments regulate nonpoint source pollution? A comparative perspective. Boston College Environmental Affairs Law Review 42(1). [online] URL: http://lawdigitalcommons.bc.edu/ealr/vol42/iss1/2

Crouch, B. R. 1981. Innovation and farm development: a multidimensional model. Pages 119-134 in B. R. Crouch and S. Chamala, editors. Extension education and rural development. Wiley and Sons, Brisbane, Australia.

Department of Primary Industries. 2010. Invasive plants and animals policy framework. Department of Primary Industries, Melbourne, Australia.

Derbaix, C., and P. Vanden Abeele. 1985. Consumer inferences and consumer preferences. The status of cognition and consciousness in consumer behaviour theory. International Journal of Research in Marketing 2:157-174. http://dx.doi. org/10.1016/0167-8116(85)90009-6

Elliot, A., and M. Stroud 2001. Prediction of nutrient loads entering Lake Taupo under various land use scenarios. NIWA Client Report EVW01224. NIWA, Hamilton, New Zealand.

Eskeland, G. S., and E. Jiminez. 1991. Choosing policy instruments for pollution control. Review, Policy, Research and External Affairs Working Paper No. 624. World Bank, Washington, D.C., USA.

Godwin, A. 2016. Proposed 'pollution diet' spurs controversy. Urban Water Management 4(4). [online] URL: http://www. waterworld.com/articles/uwm/articles/print/volume-4/issue-4/viewpoint/ proposed-pollution-diet-spurs-controversy.html

Goulder, L. H., and I. W. H. Parry. 2008. Instrument choice in environmental policy. Review of Environmental Economics and Policy 2(2):152-174. http://dx.doi.org/10.1093/reep/ren005

Greenhalgh, S., and M. Selman. 2014. Policy instruments for ecosystem services. Landcare Research Science Series No. 42. Manaaki Whenua Press, Lincoln, New Zealand.

Grimble, R., and K. Wellard. 1997. Stakeholder methodologies in natural resource management: a review of principles, contexts, experiences and opportunities. Agricultural Systems 55 (2):173-193. http://dx.doi.org/10.1016/s0308-521x(97)00006-1

Gunningham, N., P. Grabosky, and D. Sinclair. 1998. Smart regulation: designing environmental policy. Oxford University Press, New York, New York, USA.

Henderson, R. M., and K. B. Clark. 1990. Architectural innovation: the reconfiguration of existing product technologies and the failure of established firms. Administrative Science Quarterly 35(1):9-30. http://dx.doi.org/10.2307/2393549

Henderson, J. E., and R. E. Quandt. 1980. Micro economic theory: a mathematical approach. McGraw-Hill, New York, New York, USA.

Holley, C., N. Gunningham, and C. Shearing. 2013. The new environmental governance. Routledge, London, UK.

Howe, C. W. 2000. Protecting public values in a water market setting: improving water markets to increase economic efficiency and equity. University of Denver Law Review 3(2):357-372.

Hunter, J. 2004. Investigating the complexity of outsourcing decisions: an interpretive approach. Dissertation. University of New England, Armidale, New South Wales, Australia.

Kaine, G., S. Greenhalgh, W. Boyce, R. Lourey, J. Young, E. Reed, B. Keenan, and S. Mackay. 2017. A microeconomic perspective on the role of efficiency and equity criteria in designing natural resource policy. Ecology and Society 22(1):50. https://doi. org/10.5751/ES-09133-220150

Kaine, G., and M. Higson. 2006a. Understanding variety in landholders' responses to resource policy. Australasian Agribusiness Review 14(6).

Kaine, G., and M. Higson. 2006b. Policy change as innovation. Practice Change Research Working Paper 02/06. Department of Primary Industries, Tatura, Victoria, Australia.

Kaine, G., M. Higson, J. Sandall, and R. Lourey. 2006. Policy as an innovation: case studies in Australia and New Zealand. Practice Change Research Working Paper 07/06. Department of Primary Industries, Tatura, Victoria, Australia.

Kaine, G., F. Johnson, R. Lourey, J. Ford, B. Keeble, and M. Higson. 2008. Approaches to managing nutrient emissions in the Macalister Irrigation District. Final report. Practice Change Research Victorian Government Department of Primary Industries, Tatura, Victoria, Australia.

Kaine, G., and B. Keeble. 2007. Organisational relationships in natural resource policy. Department of Primary Industries, Tatura, Victoria, Australia. 
Kaine, G., and R. Lourey. 2012. An economic justification for government intervention in the control of wild dogs and primary instrument selection. Service Design Research Working Paper 01-12. Department of Primary Industries, Tatura, Victoria, Australia.

Kaine, G., H. Murdoch, R. Lourey, and D. Bewsell. 2010. A framework for understanding individual response to regulation. Food Policy 35:531-537. http://dx.doi.org/10.1016/i.foodpol.2010.06.002

Kapferer, J., and G. Laurent. 1986. Consumer involvement profiles: a new practical approach to consumer involvement. Journal of Advertising Research 25(6):48-56.

Keeble, B., G. Kaine, and J. Hunter. 2008. A new framework to investigate how organisational relationships support natural resource policy implementation: a case study of irrigation policy in the Shepparton Irrigation Region. Department of Primary Industries, Tatura, Victoria, Australia.

Kerr, S., S. Greenhalgh, and G. Simmons. 2015. The Taupo nitrogen market: the world's only diffuse source trading program. Motu Note No. 20. Motu Economic and Public Policy Research Trust, Wellington, New Zealand.

King, C. 2008. North east wild dog management group. Action plan evaluation 2005-2008. Department of Primary Industries, Melbourne, Australia.

Knowler, D., and B. Bradshaw. 2007. Farmers' adoption of conservation agriculture: a review and synthesis of recent research. Food Policy 32:25-48. http://dx.doi.org/10.1016/j. foodpol.2006.01.003

Legge, K. 2005. Management work and organisations: human resource management, rhetoric's and realities. Anniversary edition. Palgrave Macmillan, New York, New York, USA.

Lourey, R., G. Kaine, A. Davies, and J. Young. 2011. Landholder responses to incentives for wild dog control. Service Design Working Paper 08-11. Department of Primary Industries, Tatura, Victoria, Australia.

Mees, H. L. P., J. Dijk, D. van Soest, P. P. J. Driessen, M. H. F. M. W. van Rijswick, and H. Runhaar. 2014. A method for the deliberate and deliberative selection of policy instrument mixes for climate change adaptation. Ecology and Society 19(2):58. http://dx.doi.org/10.5751/ES-06639-190258

Myles, G. D. 1995. Public economics. Cambridge University Press, Cambridge, UK. http://dx.doi.org/10.1017/cbo9781139170949

Office of Technology Assessment (OTA). 1995. Environmental policy tools: a user's guide. OTA-ENV-634. U.S. Government Printing Office, Washington, D.C., USA.

Ostrom, E. 2009. A general framework for analyzing sustainability of social-ecological systems. Science 325 (5939):419-422. http://dx.doi.org/10.1126/science.1172133

Pannell, D. J. 2008. Public benefits, private benefits, and policy mechanism choice for land-use change for environmental benefits. Land Economics 84(2):225-240. http://dx.doi.org/10.3368/ $\underline{\text { le.84.2.225 }}$

Petris, S. 2004. Making sense of recent development of public sector governance. Department of Primary Industries, Victoria, Australia.
Porter, M. E. 1985. Competitive advantage-creating and sustaining superior performance. Free Press, New York, New York, USA.

Porter, M. E. 1996. What is strategy? Harvard Business Review 74 (6):61-78.

Randall, A. 1983. The problem of market failure. Natural Resources Journal 23:131-148.

Rist, R. C. 1998. Choosing the right policy instrument at the right time: the contextual challenges of selection and implementation. Pages 149-164 in M.-L. Bemelmans-Videc, R. C. Rist, and E. Vedung, editors. Carrots, sticks and sermons: policy instruments $\&$ their evaluation. Transaction Publishers, New Brunswick, New Jersey, USA.

Rose, A., and B. Stevens. 1993. The efficiency and equity of marketable permits for $\mathrm{CO}_{2}$ emissions. Resource and Energy Economics 15:117-146. http://dx.doi.org/10.1016/0928-7655(93) 90021-L

Rousseau, D. M. 1990. New hire perceptions of their own and their employer's obligations: a study of psychological contracts. Journal of Organisational Behaviour 11(5):389-400. http://dx.doi. org/10.1002/job.4030110506

Russell, C. S., and P. T. Powell. 1999. Practical considerations and comparison of instruments of environmental policy. Chapter 21 in J. C. J. M. van den Bergh, editor. Handbook of environmental and resource economics. Edward Elgar Publishing, Cheltenham, UK. http://dx.doi.org/10.4337/9781843768586.00032

Shih, C. F. and A. Venkatesh. 2004. Beyond adoption: development and application of a use-diffusion model. Journal of Marketing 68:59-72. http://dx.doi.org/10.1509/jmkg.68.1.59.24029

Smith, C. A., and C. A. Sime. 2007. Policy issues related to wolves in the Northern Rocky Mountains. Pages 391-402 in Transactions of the 72nd North American Wildlife and Natural Resources Conference. Wildlife Management Institute, Gardners, Pennsylvania, USA.

Stern, N. 2007. The economics of climate change: the Stern review. Cambridge University Press, Cambridge, UK. http://dx.doi. org/10.1017/cbo9780511817434

Taylor, C., S. Pollard, S. Rocks, and A. Angus. 2012. Selecting policy instruments for better environmental regulation: a critique and future research agenda. Environmental Policy and Governance 22:268-292. http://dx.doi.org/10.1002/eet.1584

Tinbergen, I. 1950. On the theory of economic policy. Elsevier North-Holland, Amsterdam, Netherlands.

Tversky, A. 1972. Elimination by aspects: a theory of choice. Psychological Review 79(4):281-299. http://dx.doi.org/10.1037/ h0032955

United Nations Environment Programme. 2009. Training resource manual. The use of economic instruments for environmental and natural resource management. United Nations Environment Programme, Nairobi, Kenya.

Vatn, A., and D. W. Bromley. 1997. Externalities - a market model failure. Environmental and Resource Economics 9(2):135-151. http://dx.doi.org/10.1007/bf02441375 
Vedung, E. 1998. Policy instruments: typologies and theories. Pages 21-58 in M.-L. Bemelmans-Videc, R. C. Rist, and E. Vedung, editors. Carrots, sticks and sermons: policy instruments $\&$ their evaluation. Transaction Publishers, New Brunswick, New Jersey, USA.

Velasquez, M., and P. T. Hester. 2013. An analysis of multi-criteria decision making methods. International Journal of Operations Research 10(2):56-66.

Waikato Regional Council. 2014. Waikato regional plan: variation 5-Lake Taupo catchment. Waikato Regional Council, Hamilton, New Zealand.

Williamson, O. E. 1979. Transaction-cost economics: the governance of contractual relations. Journal of Law and Economics 22(2):233-261. http://dx.doi.org/10.1086/466942

Williamson, O. E. 1991. Comparative economic organization: the analysis of discrete structural alternatives. Administrative Science Quarterly 36(2):269-296. http://dx.doi.org/10.2307/2393356

Wright, V., B. Keeble, and M. Higson. 2011a. Implications for natural resource management of restructuring organisations: protecting community involvement. Service Design Research Working Paper 01-11. Victorian Government Department of Primary Industries, East Melbourne, Australia.

Wright, V., B. Keeble, and M. Higson. 2011b. Towards better NRM outcomes: optimising co-production. Service Design Research Working Paper 02-11. Victorian Government Department of Primary Industries, East Melbourne, Australia.

Young, J., and G. Kaine. 2010. Application of the policy choice framework to Lake Taupo catchment. Environment Waikato Technical Report 2010/20. Environment Waikato, Hamilton, New Zealand. 
Appendix 1. Selected policy choice framework decision trees

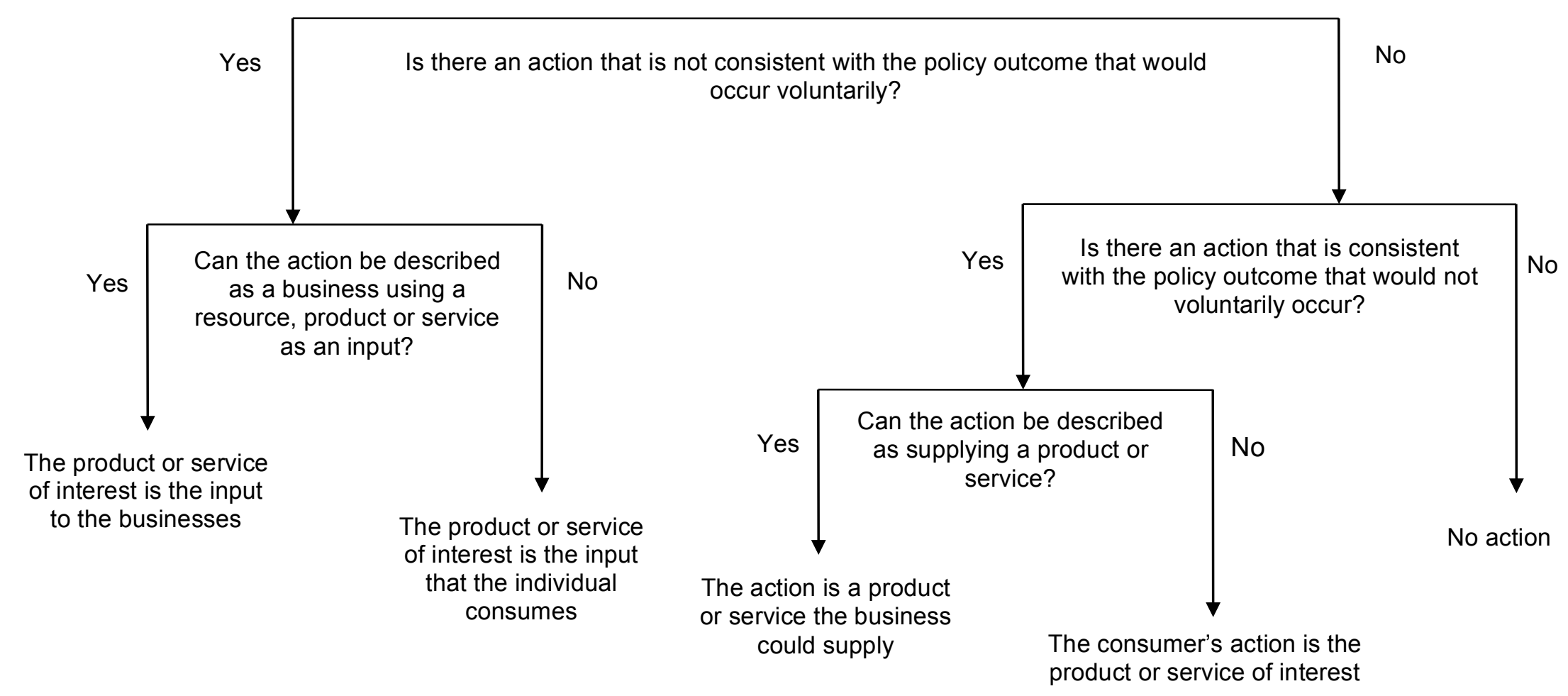

Tree 1: Policy and products tree 


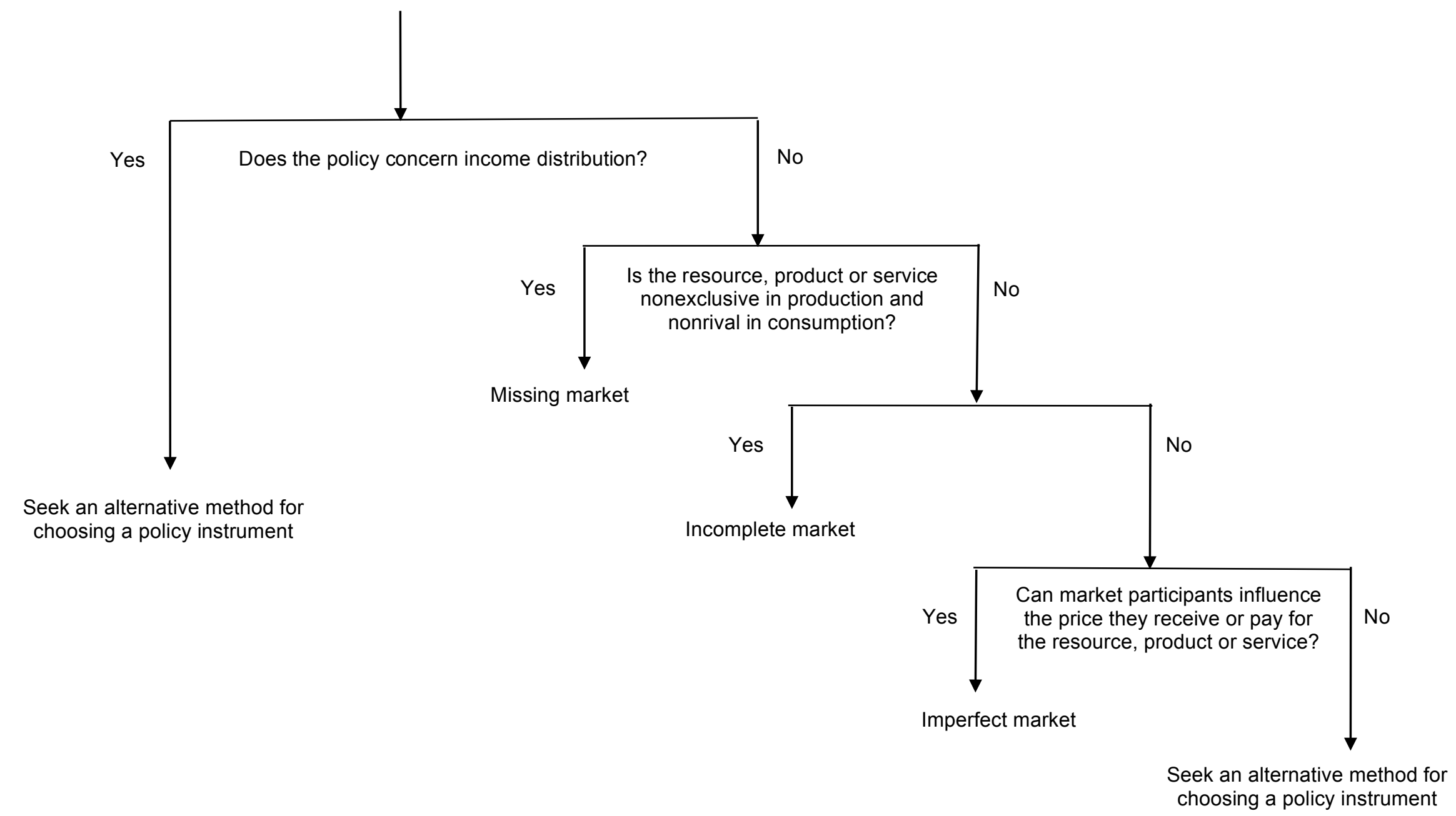

Tree 2: Economic justification tree 


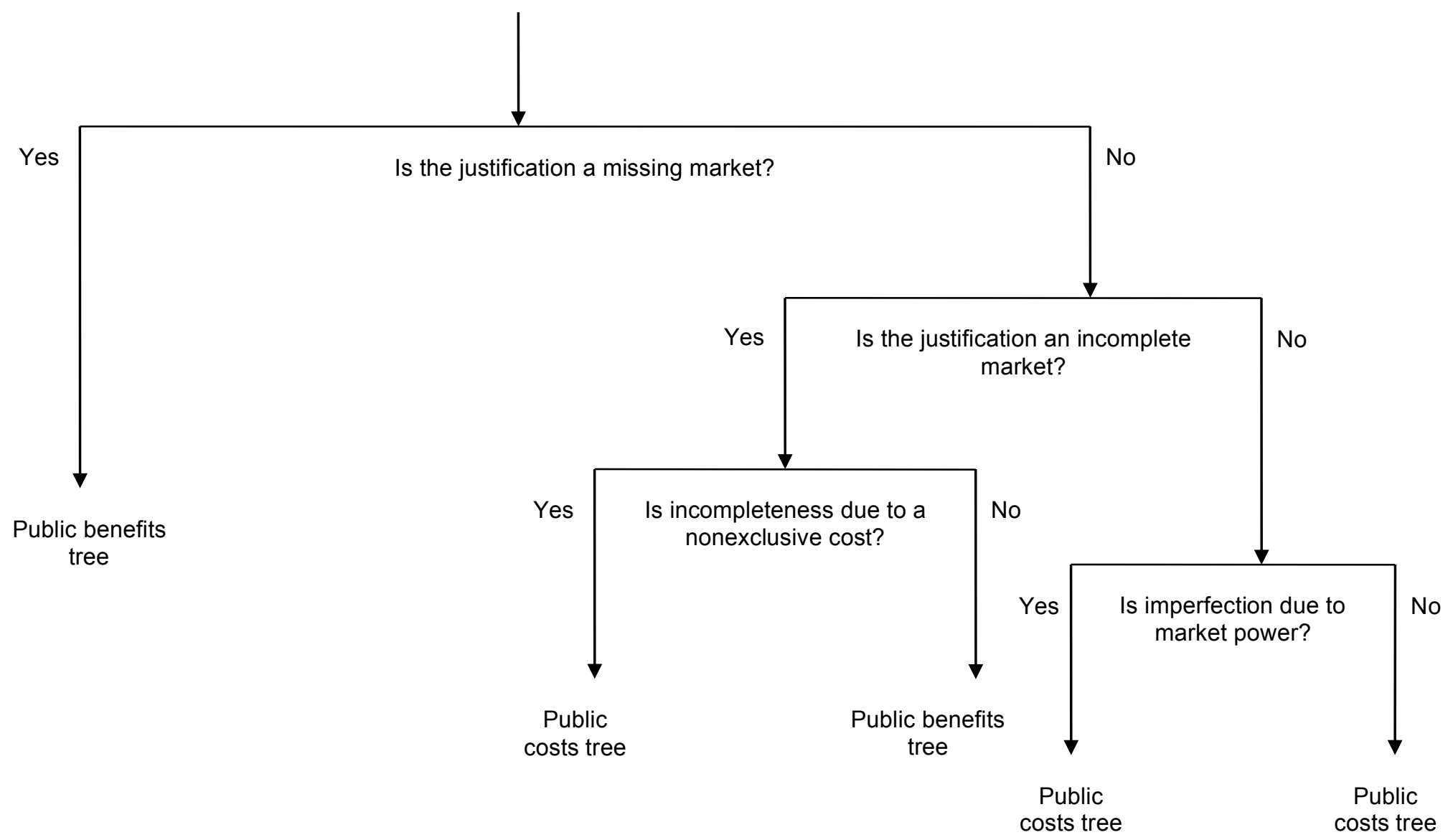

Tree 3: Primary instrument tree 


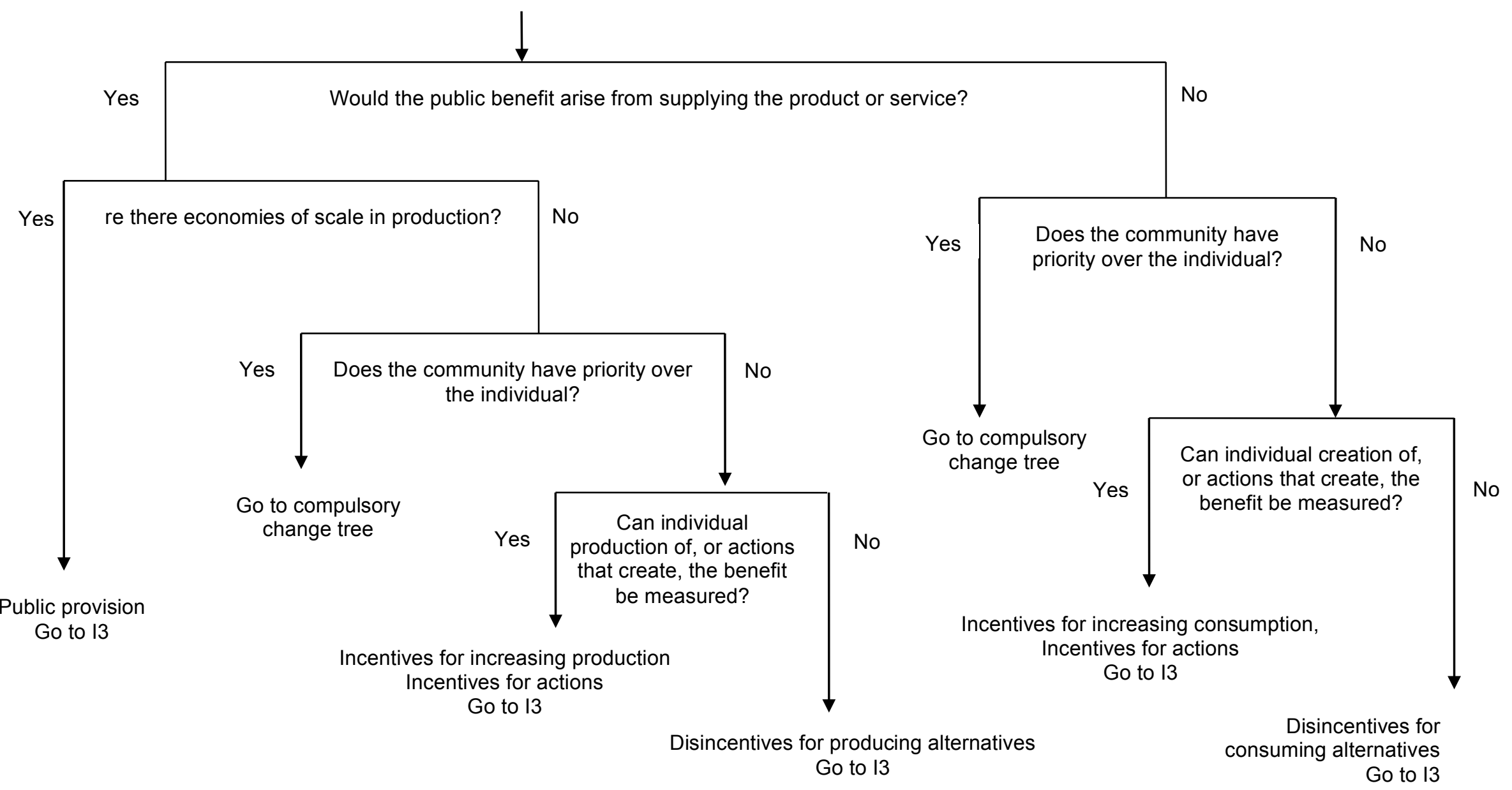

Tree 4: Public benefits tree 


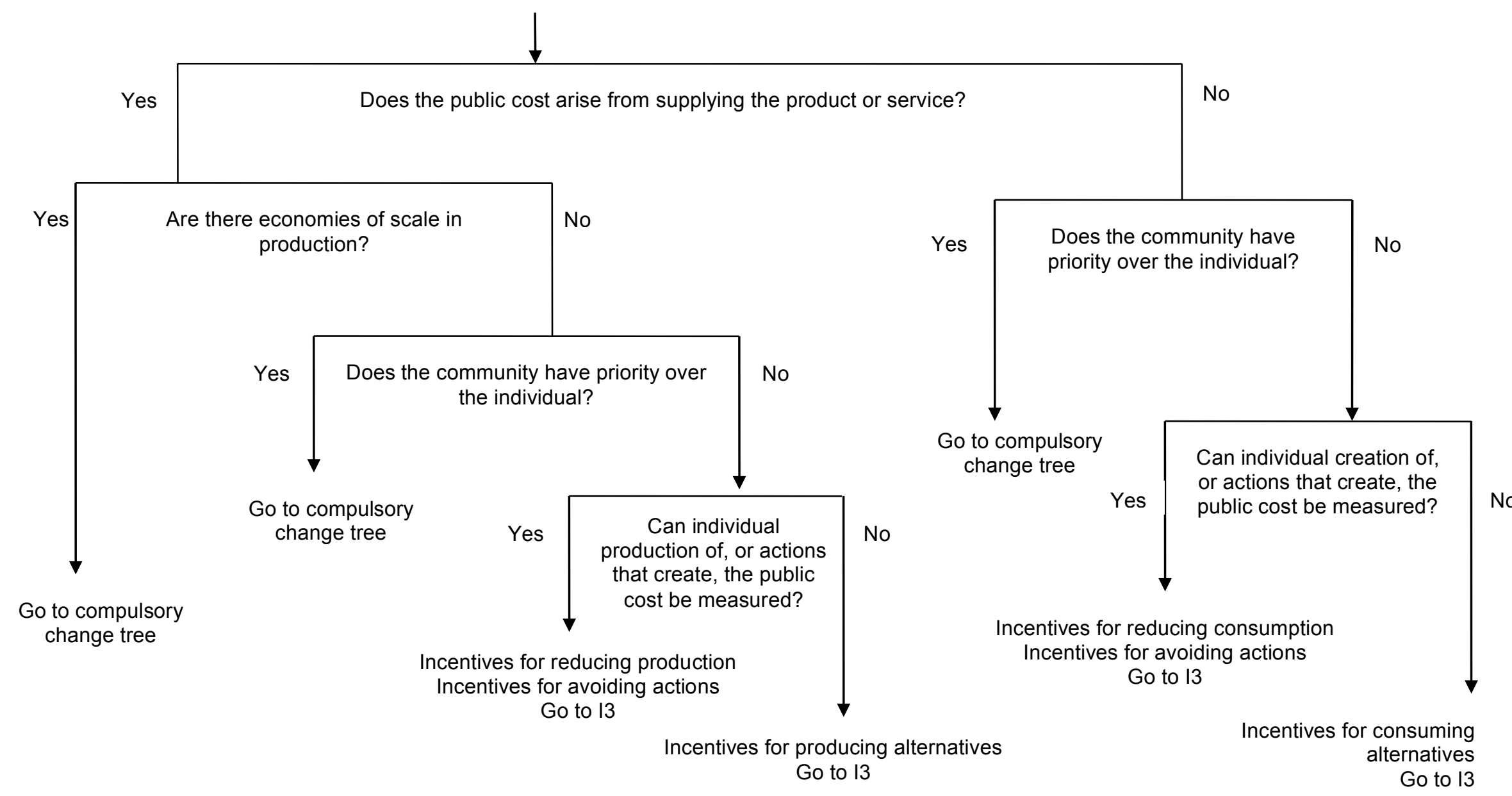

Tree 5: Public costs tree 


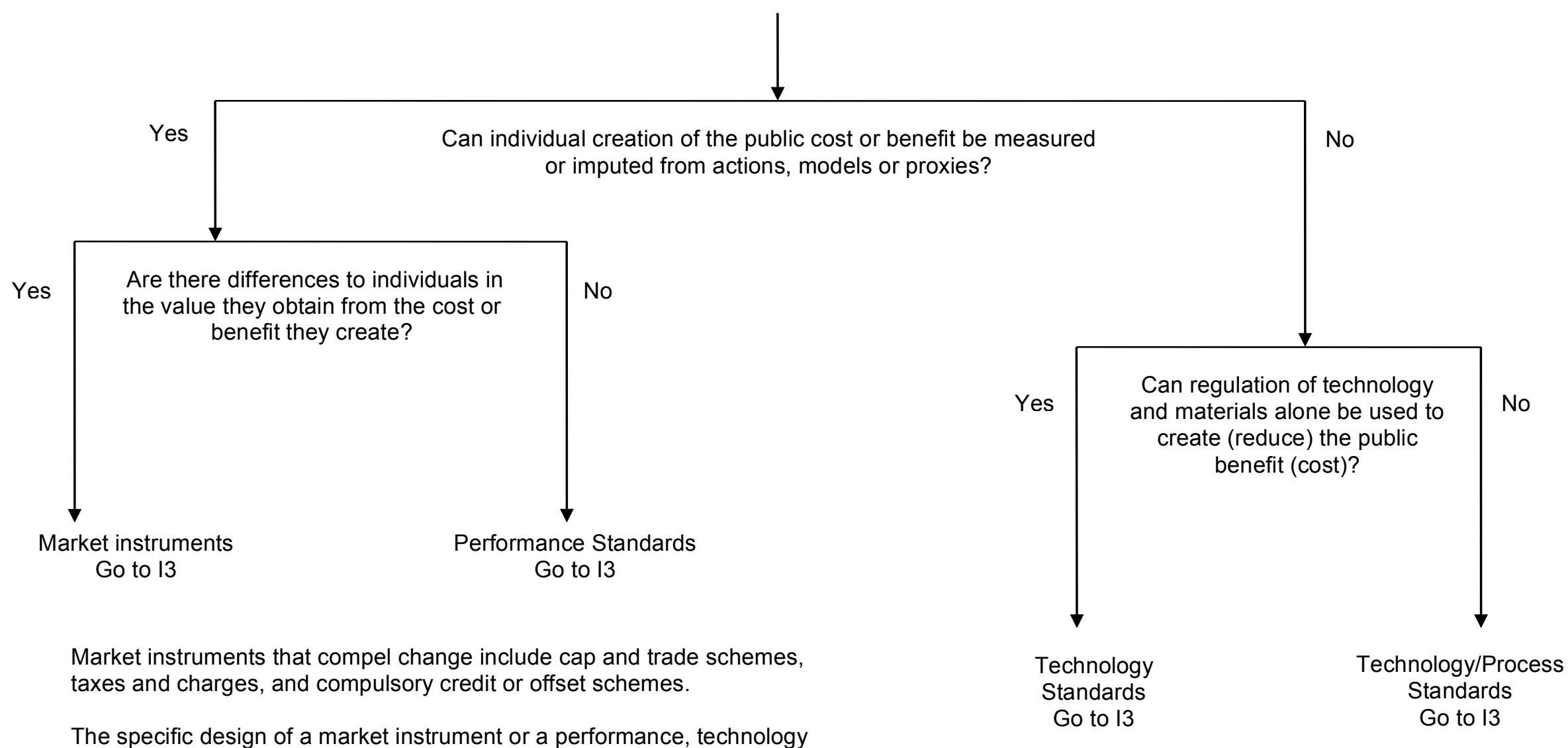

or process standard depends on contextual factors.

Kaine and Lourey (2012)

Tree 6: Compulsory change tree 